Julia Nowowiejska ${ }^{1}$, Monika Emilia Król ${ }^{1}$, Paulina Dlużniewska ${ }^{l}$, Magdalena Olszyńskal, Anna Baran², Iwona Flisiak ${ }^{2}$

\title{
SCABIES - STILL CURRENT MEDICAL AND SOCIAL PROBLEM. A RETROSPECTIVE ANALYSIS OF 193 CASES
}

\section{ŚWIERZB - NADAL AKTUALNY PROBLEM MEDYCZNY I SPOŁECZNY. ANALIZA RETROSPEKTYWNA 193 PRZYPADKÓW}

\author{
'Students' Scientific Society at the Department of Dermatology and Venereology, Medical \\ University of Bialystok \\ ${ }^{2}$ Department of Dermatology and Venereology, Medical University of Bialystok \\ ${ }^{1}$ Studenckie Koło Naukowe przy Klinice Dermatologii i Wenerologii Uniwersytetu \\ Medycznego w Białymstoku \\ ${ }^{2}$ Klinika Dermatologii i Wenerologii Uniwersytetu Medycznego w Białymstoku
}

\begin{abstract}
INTRODUCTION. Scabies is a parasitic skin disease caused by Sarcoptes scabiei. About 200 million cases worldwide each year in people of all ages are reported.

AIM OF STUDY. Retrospective analysis of records of patients hospitalized at the Department with scabies.

MATERIALS AND METHODS. Six-year retrospective analysis of medical records of patients hospitalized with scabies at the Department of Dermatology. Gender, age of patients, comorbidities, clinical course of the disease and treatment were considered.

Results In this period 193 patients were hospitalized with scabies, 96 females (49.7\%) and 97 males (50.3\%), including 33 children (17\%). Mean age of patients was 52.9. Skin lesions persisted 142 days in average; reoccurrence was noted in $14 \%$ of cases. Lesions were observed most often in winter (31\%). The most common manifestations were erosions $(80.8 \%)$, excoriations $(73.6 \%)$, papules $(72.6 \%)$ and crusts $(24.3 \%)$, localized mainly on trunk (92\%), lower (91\%) and upper (86\%) limbs. 181 patients $(93.8 \%)$ reported pruritus which intensified at night in 35.8\%. Previous contact with people with scabies reported 41 patients $(21 \%)$. The most common comorbidity was hypertension, diabetes mellitus and coronary heart disease. Accompanying dermatoses were eczema, secondary superinfection and psoriasis. 85 patients $(44 \%)$ were overweight or obese. Patients received mostly topical permethrin (57\%), crotamiton (29\%), glicocorticosteroids (73\%) and antibiotics (11\%), also oral antihistamines $(91 \%)$.

CONCLUSIONS. Analysis revealed more frequent occurrence in adults with no evident sex prevalence. Greater incidence in winter may be caused by people's tendency to spend more time indoors closer to each other at this time of year. Pruritus, the most common subjective symptom, typically worsens at night.
\end{abstract}

Key words: scabies, pruritus, Sarcoptes scabiei

\section{STRESZCZENIE}

WSTĘP. Świerzb jest pasożytniczą chorobą skóry spowodowaną przez świerzbowca ludzkiego. Na świecie odnotowuje się 200 milionów przypadków rocznie u ludzi w każdym wieku.

CEL PRACY. Analiza retrospektywna dokumentacji pacjentów hospitalizowanych w Klinice z powodu świerzbu.

MATERIALY I METODY. Analizie poddano dokumentację medyczną pacjentów hospitalizowanych z powodu świerzbu w Klinice w latach 2010-2016. Analizowano wiek pacjentów, choroby współistniejące, przebieg kliniczny choroby oraz zastosowane leczenie. 
WYNIKI. Hospitalizowano 193 pacjentów ze świerzbem, 96 kobiet (49,7\%) i 97 mężczyzn (50,3\%), w tym 33 dzieci (17\%). Średni wiek pacjentów wynosił 52,9 roku. Zmiany skórne utrzymywały się średnio 5 miesięcy; nawroty odnotowano w 14\% przypadków. Objawy dermatozy występowały najczęściej zimą i wiosną. Najczęstszymi objawami były nadżerki $(80,8 \%)$, przeczosy $(73,6 \%)$, grudki $(72,6 \%)$ i strupy $(24,3 \%)$, zlokalizowane przeważnie na tułowiu (92\%), kończynach dolnych (91\%) i górnych (86\%). U 181 pacjentów $(93,8 \%)$ wystąpił świąd, nasilający się w nocy u 35,8\% z nich. Najczęstszą chorobą współistniejącą było nadciśnienie tętnicze, cukrzyca i choroba wieńcowa. Wśród towarzyszących dermatoz odnotowano wyprysk, nadkażenie bakteryjne oraz łuszczycę. 85 pacjentów (44\%) miało nadwagę lub było otyłymi. Większość pacjentów leczono miejscowo permetryną (57\%), krotamitonem (29\%), glikokortykosteroidami (73\%) oraz antybiotykami (11\%) i doustnymi lekami przeciwhistaminowymi (91\%).

WNIOSKI. Analiza ujawniła częstsze występowanie świerzbu u dorosłych bez wyraźnej przewagi płci. Większa liczba przypadków występujących zimą może mieć związek z częstszym pozostawaniem ludzi w domu i w bliższej wzajemnej styczności o tej porze roku. Świąd jest najczęstszym objawem subiektywnym, który typowo nasila się w nocy.

Slowa kluczowe świerzb, świą, Sarcoptes scabiei

\section{INTRODUCTION}

Scabies is a dermatosis occurring in people of all ages and in all socioeconomic conditions caused by Sarcoptes scabiei mites $(1,2)$. Its predominant symptom is intense pruritus, often intensifying at night, caused by a delayed allergic reaction to the presence of the parasite itself, its faeces and eggs (1). The clinical features of scabies are papules with erosions and excoriations located around the wrists, fingers, elbows, armpits, genitals, torso and buttocks, in newborns and children lesions can also occur on the head and face (1) (Fig.1). Scabies is transmitted by direct contact with an infected person, which is why it is most common among family members, people in nursing homes, prisons, children attending kindergartens or nurseries and among migrant refugees (1). The topical medications are the most important in the treatment, but it is also important to maintain an appropriate hygiene regimen $(2,3)$.

The Global Burden of Disease study estimated that in 2015, over 200 million people in the world were infected with Sarcoptes scabiei (4). In Poland since 2008 scabies cases have been no longer registered, however epidemiological data from 2001-2008 indicate that it was the most frequent parasitosis in the country, and the total number of registered cases in this period reached over 100,000 (5). Due to the persistence of the high number of cases of this dermatosis, WHO in 2017 included scabies in the so-called group Neglected Tropical Diseases to improve the global control, prevention, elimination and eradication of this disease $(6,7)$. In May 2018, IACS (International Alliance for the Control of Scabies) published diagnostic criteria for scabies, the use of which will improve the control of scabies around the world (8).

Scabies is still a significant medical problem due to high prevalence, especially in countries with

\section{WSTĘP}

Świerzb jest dermatozą występującą u ludzi w każdym wieku i w każdych warunkach socjoekonomicznych, wywołaną przez roztocza Sarcoptes scabiei $(1,2)$. Jej dominującym objawem jest intensywny świąd, często nasilający się w nocy, spowodowany opóźnioną reakcją alergiczną na obecność samego pasożyta, jego odchodów i jaj (1). W obrazie klinicznym stwierdza się grudki z nadżerkami i przeczosami zlokalizowane w okolicy nadgarstków, palców, łokci, pach, narządów płciowych, tułowia oraz pośladków, u noworodków i dzieci zmiany mogą występować również na głowie i twarzy (1) (Ryc.1.). Świerzb jest przenoszony przez bezpośrednią styczność z osobą zakażoną, dlatego najczęściej występuje wśród członków rodziny, osób przebywających w domach opieki, więzieniach, dzieci uczęszczających do przedszkola lub żłobka oraz wśród migrujących uchodźców (1). W leczeniu główne znaczenie mają preparaty do stosowania miejscowego, lecz bardzo istotne jest również utrzymanie odpowiedniego reżimu higienicznego $(2,3)$.

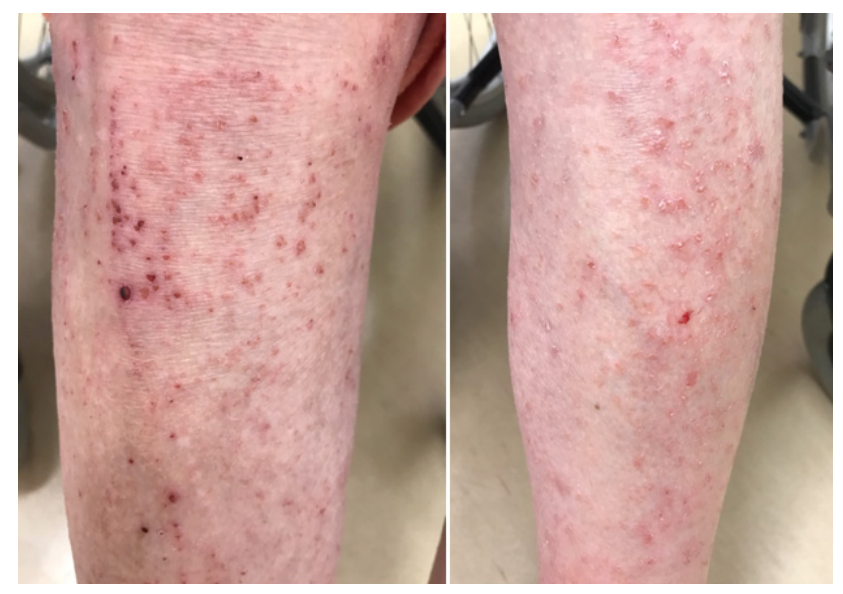

Fig. 1. Erythematous-papular lesions with crusts and excoriations in scabies affecting both calves.

Ryc.1. Zmiany rumieniowo-grudkowe, strupy i przeczosy w przebiegu świerzbu na obu podudziach. 
high humidity and developing countries, but also due to complications caused by intense scratching, causing bacterial infections that can lead to sepsis, glomerulonephritis or rheumatic heart disease $(7,9,10,11)$. It is also a social problem because it causes difficulties with concentration, sleeping disorders and stigmatization $(7,11)$.

\section{AIM OF STUDY}

A retrospective analysis of epidemiological and clinical aspects among patients hospitalized with scabies at the Department of Dermatology and Venereology, Medical University of Bialystok, basing on convenience sample.

\section{MATERIALS AND METHODS}

Medical records of patients hospitalized with scabies at the Department within six years were retrospectively analyzed, considering gender, age of patients, course of the disease, administered treatment and comorbidities.

\section{RESULTS}

There were 193 patients hospitalized at the Department within years 2010-2016. In the analyzed group there were 96 women $(49.7 \%)$ and 97 men (50.3\%), including 33 children (17.1\%). The age of the patients ranged between 2 to 87 years (mean age 52.9 years old). In the group of children, there were 19 boys ( $57.6 \%$ of all children) and 14 girls $(42.4 \%$ of all children). Most of patients were between 60 and 79 years old (32.6\%) and 133 patients $(68.9 \%)$ were over 40 years old. The mean age of children was 8.4 years old. Skin lesions persisted from one day to 5 years, approximately 5 months in average. Reoccurrence of skin lesions was observed in 25 patients (14\%). Patients presented to doctor most often in winter (31\%) and spring (30\%). The most common skin lesions were erosions in $156(80.8 \%)$, excoriations in 142 (73.6\%), papules in $140(72.6 \%)$, crusts in $47(24.3 \%)$ and erythematous papules in 27 patients (14\%) (Fig. 2 ). In addition, there were other skin lesions such us: erythematous exfoliation in 18 people $(9.3 \%)$, erythema in $17(8.8 \%)$, nodules in $6(4.2 \%)$, vesicles in $6(3.1 \%)$, lichenification in $3(1.5 \%)$, pustules in $2(1 \%)$ and hyperkeratosis in $1(0.5 \%)$. In children papules occurred in all 33 patients, excoriations in 29 $(88 \%)$, erosions in $25(75.6 \%)$ and crusts in 9 patients (27.3\%). Skin lesions were most frequently observed over the trunk in 178 patients $(92 \%)$ and on the limbs: lower in 176 patients $(91 \%)$, upper in $166(86 \%)$ and on both limbs simultaneously in 154 patients $(80 \%)$.
Badanie The Global Burden of Disease oszacowało, że w 2015 roku ponad 200 milionów ludzi na świecie było zarażonych świerzbowcem ludzkim (4). W Polsce od 2008 roku świerzb nie był już rejestrowany, jednak dane epidemiologiczne z okresu 2001-2008 wskazują, że była to najczęściej występująca parazytoza na terenie kraju, a łączna liczba zarejestrowanych przypadków w tym okresie sięgała ponad 100 tysięcy (5). W związku z utrzymywaniem się liczby zachorowań na tę dermatozę, WHO w 2017 roku włączyło świerzb do grupy tzw. zaniedbanych chorób tropikalnych (ang. Neglected Tropical Diseases) w celu polepszenia globalnej kontroli, prewencji, eliminacji i eradykacji tego schorzenia $(6,7)$. W maju 2018 roku IACS (International Alliance for the Control of Scabies) opublikowało kryteria diagnostyczne świerzbu, których stosowanie umożliwi polepszenie kontroli zachorowań na świerzb na całym świecie (8).

Świerzb nadal stanowi istotny problem medyczny z powodu dużego rozpowszechnienia, szczególnie w krajach o dużej wilgotności oraz rozwijających się, ale również ze względu na powikłania spowodowane intensywnym drapaniem się, powodujących zakażenia bakteryjne, które mogą doprowadzić do posocznicy, kłębuszkowego zapalenia nerek czy reumatycznej choroby serca $(7,9,10,11)$. Jest to także problem społeczny, ponieważ wywołuje trudności z koncentracją i zaburzenia snu oraz stygmatyzację $(7,11)$.

\section{CEL PRACY}

Analiza retrospektywna aspektów epidemiologicznych i klinicznych wśród pacjentów hospitalizowanych w Klinice Dermatologii i Wenerologii UMB z powodu świerzbu na zasadzie doboru dogodnościowego.

\section{MATERIALY I METODY}

Analizie retrospektywnej poddano dokumentację medyczną chorych hospitalizowanych z powodu świerzbu w Klinice na przestrzeni sześciu lat. Analizowano dane: płeć, wiek pacjentów, przebieg kliniczny choroby, zastosowane leczenie oraz choroby wspólistniejące.

\section{WYNIKI}

W latach 2010-2016 z powodu świerzbu hospitalizowano w Klinice 193 pacjentów. Analizowana grupa liczyła 96 kobiet (49,7\%) i 97 mężczyzn (50,3\%), w tym 33 dzieci (17,1\%). Wiek pacjentów był w granicach od 2 do 87 lat (średnio 52,9 roku). W grupie dzieci było 19 chłopców (57,6\% wszystkich dzieci) i 14 dziewcząt (42,4\% dzieci). Większość pacjentów była w przedziale wieku 60-79 lat (32,6\%), a 133 pacjentów $(68,9 \%)$ w wieku powyżej 40 lat. Średni wiek dzieci wynosił 8,4 roku. Okres utrzymywania się zmian skórnych wynosił od jednego dnia do 5 lat, średnio około 5 miesięcy. 


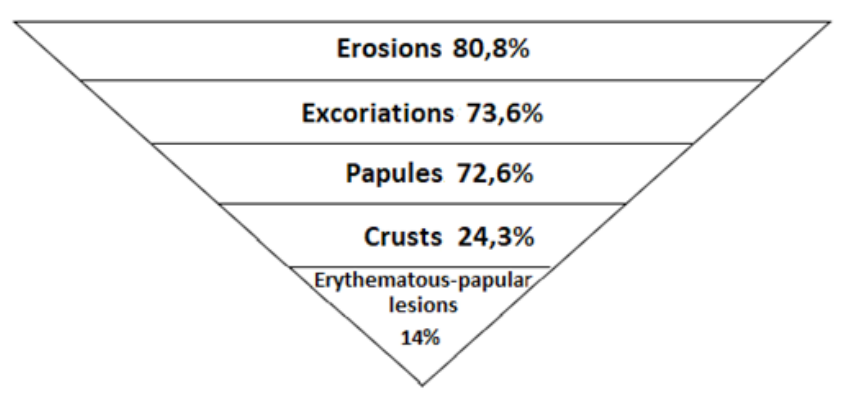

Fig. 2. The most common skin manifestations.

Ryc. 2. Najczęściej występujące zmiany skórne.

Skin lesions occurred in children simultaneously on upper and lower limbs as well as over the trunk. The most frequently reported symptom was pruritus, which occurred in 181 patients $(93.8 \%)$, intensifying at night in 69 patients $(35.8 \%)$. Previous contact with people with scabies was reported by 41 patients (21\%). In 137 patients $(71 \%)$ comorbidities were observed: arterial hypertension - 52 patients $(26.9 \%)$, diabetes mellitus 25 patients $(13 \%)$, ischemic heart disease - 20 patients $(10.4 \%)$, atrial fibrillation - 19 patients $(9.8 \%)$, mental illness - $18(9.3 \%)$, heart failure - $12(6.2 \%)$, asthma in 10 patients $(5.2 \%)$, thyroid disease in 9 patients $(4.7 \%)$ and alcohol addiction in 8 patients (4.1\%) (Table 1). Among accompanying dermatoses the most common were eczema $11.4 \%$, bacterial superinfection $(7.3 \%)$, psoriasis $(6.2 \%)$ and cutaneous fungal infections (5.7\%) (Tab. 2). The most frequent abnormalities found in laboratory investigations were: eosinophilia in 34\%, anaemia in $25 \%$, elevated C-reactive protein in $10.4 \%$ of patients. $44 \%$ of patients had excessive body weight, $22.8 \%$ of patients were overweight (BMI $25.0-30.0)$ and $21.2 \%$ of all were obese (BMI $\geq 30.0$ ). Patients were treated topically with permethrin $(57 \%)$, crotamiton (29\%), then glucocorticosteroids (73\%), antibiotics (11\%) and also oral antihistamines (91\%).

\section{DISCUSSION}

At our Department the lowest number of people hospitalized with scabies within the years 2010-2016 was noted in 2012 (Fig. 3). In the analyzed period the majority of patients were between 60 and 79 years old. This may have been caused by the presence of comorbidities at this age, decreased general well-being and negligence of hygiene in elderly people, living in shelters and nursing homes, where scabies infection is easily transmitted to other people. Particularly large number of patients in this age group was reported in 2010. The least prone to scabies infection were people between 18-39 years old. In this age group there were the smallest fluctuations in the number of hospitalizations over the years (oscillating between 0-6 per year). Lower incidence of scabies in this group may be a result of the greater awareness and
Nawrót zmian skórnych zaobserwowano u 25 pacjentów (14\%). Pacjenci zgłaszali się do lekarza najczęściej w porze zimowej (31\%) i wiosennej (30\%). Najczęściej występującymi zmianami skórnymi były nadżerki u 156 $(80,8 \%)$, przeczosy u $142(73,6 \%)$, grudki u $140(72,6 \%)$, strupy u $47(24,3 \%)$ oraz zmiany rumieniowo-grudkowe u 27 pacjentów (14\%) (Ryc.2.). Ponadto występowały zmiany: rumieniowo-złuszczające u 18 osób $(9,3 \%)$, rumieniowe - 17 (8,8\%), guzki - 6 (4,2\%), pęcherzyki - 6 $(3,1 \%)$, lichenifikacja - $3(1,5 \%)$, krosty - $2(1 \%)$ oraz hiperkeratoza - $1(0,5 \%)$. U dzieci grudki występowały u wszystkich 33 pacjentów, przeczosy u $29(88 \%)$, nadżerki u $25(75,6 \%)$ oraz strupy u 9 osób $(27,3 \%)$. Zmiany skórne najczęściej obserwowano na tułowiu 178 pacjentów (92\%) oraz na kończynach: dolnych 176 pacjentów (91\%) i górnych u $166(86 \%)$ a na obu jednocześnie u 154 pacjentów (80\%). U dzieci zmiany występowały jednocześnie na kończynach górnych, dolnych jak i tułowiu. Najczęściej zgłaszanymi objawami był świąd, który występował u 181 osób $(93,8 \%)$, nasilający się w nocy u 69 osób (35,8\%). Uprzednią styczność z osobami chorymi na świerzb zgłosiło 41 pacjentów (21\%). U 137 pacjentów (71\%) odnotowano występowanie chorób współistniejących: nadciśnienie tętnicze - 52 pacjentów $(26,9 \%)$, cukrzyca - 25 chorych $(13 \%)$, choroba niedokrwienna serca - 20 pacjentów (10,4\%), migotanie przedsionków - 19 pacjentów $(9,8 \%)$, choroby psychiczne - $18(9,3 \%)$, niewydolność serca - $12(6,2 \%)$, astma u 10 pacjentów $(5,2 \%)$, choroby tarczycy u 9 pacjentów $(4,7 \%)$ oraz alkoholizm u 8 pacjentów $(4,1 \%)$ (Tab. 1.). Wśród towarzyszących dermatoz najczęściej wymieniano wyprysk $11,4 \%$, nadkażenie bakteryjne $(7,3 \%)$, łuszczycę $(6,2 \%)$ oraz skórne zakażenia grzybicze $(5,7 \%)$ (Tab. 2.). W wynikach badań laboratoryjnych najczęściej stwierdzano następujące odchylenia: eozynofilię u 34\%, anemię u $25 \%$, podwyższony poziom białka C-reaktywnego u $10,4 \%$ chorych. U $44 \%$ pacjentów stwierdzono nadmierną masę ciała, w tym $22,8 \%$ pacjentów miało nadwagę (BMI 25,0-30,0), a 21,2\% pacjentów było otyłych (BMI $\geq 30,0)$. Chorych leczono miejscowo: permetryną (57\%), krotamitonem (29\%), następnie glikokortykosteroidami (73\%), antybiotykami (11\%), a także doustnie lekami przeciwhistaminowymi $(91 \%)$.

\section{DYSKUSJA}

W naszej Klinice na przestrzeni lat 2010-2016 najmniejszą liczbę osób z powodu świerzbu hospitalizowano w 2012 roku (Ryc. 3.) W analizowanym okresie najwięcej chorych było z grupy wieku 60-79 lat. Przyczyną tego mogło być występowanie w tym wieku chorób współtowarzyszących, obniżony dobrostan i zaniedbania higieniczne osób w starszym wieku, zamieszkiwanie w przytułkach, domach opieki, gdzie zakażenie łatwo przenosi się na kolejne osoby. Szczególnie dużą liczbę chorych w tej grupie wieku odnotowano w 2010 roku. 
professional activity of people and perhaps greater resistance to various dermatoses. Low number of cases was also observed in people below 18 years old. In this age group there was more than a two-fold decrease in the number of patients in 2011 compared to 2010, a two-fold increase in the number of patients in 2014 compared to 2013, and the lack of dermatosis in 2012, 2015 and 2016.
W grupie najmniej podatnej na zakażenie świerzbowcem były osoby w wieku 18-39. W tym przedziale wieku były najmniejsze wahania w liczbie hospitalizacji na przestrzeni lat (oscylowały między 0-6 rocznie). Mniejsza zapadalność na świerzb w tej grupie może wynikać z większej świadomości i aktywności zawodowej osób, a być może $\mathrm{z}$ większej odporności na różne dermatozy.

Table 1. Accompanying diseases in patients with scabies hospitalized at the Department within years 2010-2016 considering their age

Tabela 1. Choroby współistniejące u pacjentów ze świerzbem hospitalizowanych w Klinice w latach 2010-2016 z uwzględnieniem wieku

\begin{tabular}{|c|c|c|c|c|c|c|c|}
\hline $\begin{array}{c}\text { Choroby } \\
\text { wspólistniejące }\end{array}$ & $\leq 17$ r.ż. & 18-39 r.ż. & 40-59 r.ż. & 60-79 r. $\dot{z}$ & $\geq 80$ r.ż. & $\begin{array}{c}\text { Osoby dorosłe } \\
(\geq 18 \text { r.ż.) }\end{array}$ & Razem \\
\hline Nadciśnienie tętnicze & $\begin{array}{l}\mathbf{0 / 3 3} \\
(0 \%)\end{array}$ & $\begin{array}{l}\mathbf{0} / 27 \\
(0 \%)\end{array}$ & $\begin{array}{c}\mathbf{6 / 3 6} \\
(16.7 \%)\end{array}$ & $\begin{array}{c}\mathbf{2 7 / 6 3} \\
(42.9 \%)\end{array}$ & $\begin{array}{c}19 / 34 \\
(55.9 \%)\end{array}$ & $\begin{array}{l}\mathbf{5 2} / \mathbf{1 6 0} \\
(32.5 \%)\end{array}$ & $\begin{array}{l}\mathbf{5 2 / 1 9 3} \\
(26.9 \%) \\
\end{array}$ \\
\hline Otyłość & $\begin{array}{l}\mathbf{0 / 3 3} \\
(0 \%) \\
\end{array}$ & $\begin{array}{c}\mathbf{6} / \mathbf{2 7} \\
(22.2 \%) \\
\end{array}$ & $\begin{array}{c}\mathbf{1 0 / 3 6} \\
(27.7 \%) \\
\end{array}$ & $\begin{array}{c}\mathbf{1 5} / \mathbf{6 3} \\
(23.8 \%) \\
\end{array}$ & $\begin{array}{c}10 / 34 \\
(29.4 \%)\end{array}$ & $\begin{array}{l}\mathbf{4 1 / 1 6 0} \\
(25.6 \%)\end{array}$ & $\begin{array}{l}\mathbf{4 1 / 1 9 3} \\
(21.2 \%) \\
\end{array}$ \\
\hline Cukrzyca & $\begin{array}{l}\mathbf{0 / 3 3} \\
(0 \%) \\
\end{array}$ & $\begin{array}{c}\mathbf{1 / 2 7} \\
(3.7 \%) \\
\end{array}$ & $\begin{array}{c}\mathbf{3 / 3 6} \\
(8.3 \%) \\
\end{array}$ & $\begin{array}{c}\mathbf{1 6} / \mathbf{6 3} \\
(25.4 \%) \\
\end{array}$ & $\begin{array}{c}\mathbf{5 / 3 4} \\
(14.7 \%) \\
\end{array}$ & $\begin{array}{l}\mathbf{2 5} / \mathbf{1 6 0} \\
(15.6 \%)\end{array}$ & $\begin{array}{l}\mathbf{2 5} / \mathbf{1 9 3} \\
(13 \%) \\
\end{array}$ \\
\hline Choroba wieńcowa & $\begin{array}{l}\mathbf{0} / \mathbf{3 3} \\
(0 \%)\end{array}$ & $\begin{array}{l}\mathbf{0} / \mathbf{2 7} \\
(0 \%)\end{array}$ & $\begin{array}{l}\mathbf{0 / 3 6} \\
(0 \%) \\
\end{array}$ & $\begin{array}{c}\mathbf{1 4 / 6 3} \\
(22.2 \%)\end{array}$ & $\begin{array}{c}\mathbf{6 / 3 4} \\
(17.6 \%)\end{array}$ & $\begin{array}{c}\mathbf{2 0} / \mathbf{1 6 0} \\
(12.5 \%)\end{array}$ & $\begin{array}{c}\mathbf{2 0} / \mathbf{1 9 3} \\
(10.4 \%)\end{array}$ \\
\hline Migotanie przedsionków & $\begin{array}{l}\mathbf{0 / 3 3} \\
(0 \%)\end{array}$ & $\begin{array}{l}\mathbf{0 / 2 7} \\
(0 \%)\end{array}$ & $\begin{array}{l}\mathbf{0 / 3 6} \\
(0 \%)\end{array}$ & $\begin{array}{l}\mathbf{1 2 / 6 3} \\
(19 \%)\end{array}$ & $\begin{array}{c}7 / 34 \\
(20.6 \%)\end{array}$ & $\begin{array}{l}\mathbf{1 9 / 1 6 0} \\
(11.9 \%)\end{array}$ & $\begin{array}{l}19 / 193 \\
(9.8 \%)\end{array}$ \\
\hline Choroby psychiczne & $\begin{array}{l}\mathbf{0 / 3 3} \\
(0 \%) \\
\end{array}$ & $\begin{array}{c}\mathbf{2 / 2 7} \\
(7.4 \%) \\
\end{array}$ & $\begin{array}{c}\mathbf{4 / 3 6} \\
(11.1 \%) \\
\end{array}$ & $\begin{array}{c}\mathbf{8} / \mathbf{6 3} \\
(12.7 \%) \\
\end{array}$ & $\begin{array}{c}\mathbf{4 / 3 4} \\
(11.8 \%) \\
\end{array}$ & $\begin{array}{l}\mathbf{1 8} / \mathbf{1 6 0} \\
(11 \%)\end{array}$ & $\begin{array}{l}\mathbf{1 8} / \mathbf{1 9 3} \\
(9.3 \%) \\
\end{array}$ \\
\hline Niewydolność serca & $\begin{array}{l}\mathbf{0 / 3 3} \\
(0 \%) \\
\end{array}$ & $\begin{array}{l}\mathbf{0} / 27 \\
(0 \%)\end{array}$ & $\begin{array}{l}\mathbf{0 / 3 6} \\
(0 \%) \\
\end{array}$ & $\begin{array}{c}7 / 63 \\
(11.1 \%) \\
\end{array}$ & $\begin{array}{c}\mathbf{5 / 3 4} \\
(14.7 \%) \\
\end{array}$ & $\begin{array}{l}\mathbf{1 2 / 1 6 0} \\
(7.5 \%) \\
\end{array}$ & $\begin{array}{l}12 / 193 \\
(6.2 \%) \\
\end{array}$ \\
\hline Astma & $\begin{array}{c}\mathbf{2 / 3 3} \\
(6.1 \%) \\
\end{array}$ & $\begin{array}{c}\mathbf{1} / \mathbf{2 7} \\
(3.7 \%)\end{array}$ & $\begin{array}{l}\mathbf{1 / 3 6} \\
(2.8) \\
\end{array}$ & $\begin{array}{c}\mathbf{2 / 6 3} \\
(3.2 \%) \\
\end{array}$ & $\begin{array}{c}\mathbf{4} / \mathbf{3 4} \\
(11.8 \%)\end{array}$ & $\begin{array}{c}8 / 160 \\
(5 \%) \\
\end{array}$ & $\begin{array}{l}\mathbf{1 0} / \mathbf{1 9 3} \\
(5.2 \%) \\
\end{array}$ \\
\hline Choroby tarczycy & $\begin{array}{l}\mathbf{0 / 3 3} \\
(0 \%) \\
\end{array}$ & $\begin{array}{c}1 / 27 \\
(3.7 \%) \\
\end{array}$ & $\begin{array}{l}\mathbf{0 / 3 6} \\
(0 \%) \\
\end{array}$ & $\begin{array}{c}7 / 63 \\
(11.1 \%) \\
\end{array}$ & $\begin{array}{c}1 / 34 \\
(2.9 \%) \\
\end{array}$ & $\begin{array}{l}9 / 160 \\
(5.6 \%) \\
\end{array}$ & $\begin{array}{c}9 / 193 \\
(4.7 \%) \\
\end{array}$ \\
\hline Alkoholizm & $\begin{array}{l}\mathbf{0 / 3 3} \\
(0 \%) \\
\end{array}$ & $\begin{array}{c}1 / 27 \\
(3.7 \%) \\
\end{array}$ & $\begin{array}{c}\mathbf{4 / 3 6} \\
(11.1 \%) \\
\end{array}$ & $\begin{array}{c}\mathbf{2 / 6 3} \\
(3.2 \%) \\
\end{array}$ & $\begin{array}{c}1 / 34 \\
(2.9 \%) \\
\end{array}$ & $\begin{array}{l}8 / 160 \\
(5 \%) \\
\end{array}$ & $\begin{array}{c}8 / 193 \\
(4.1 \%) \\
\end{array}$ \\
\hline
\end{tabular}

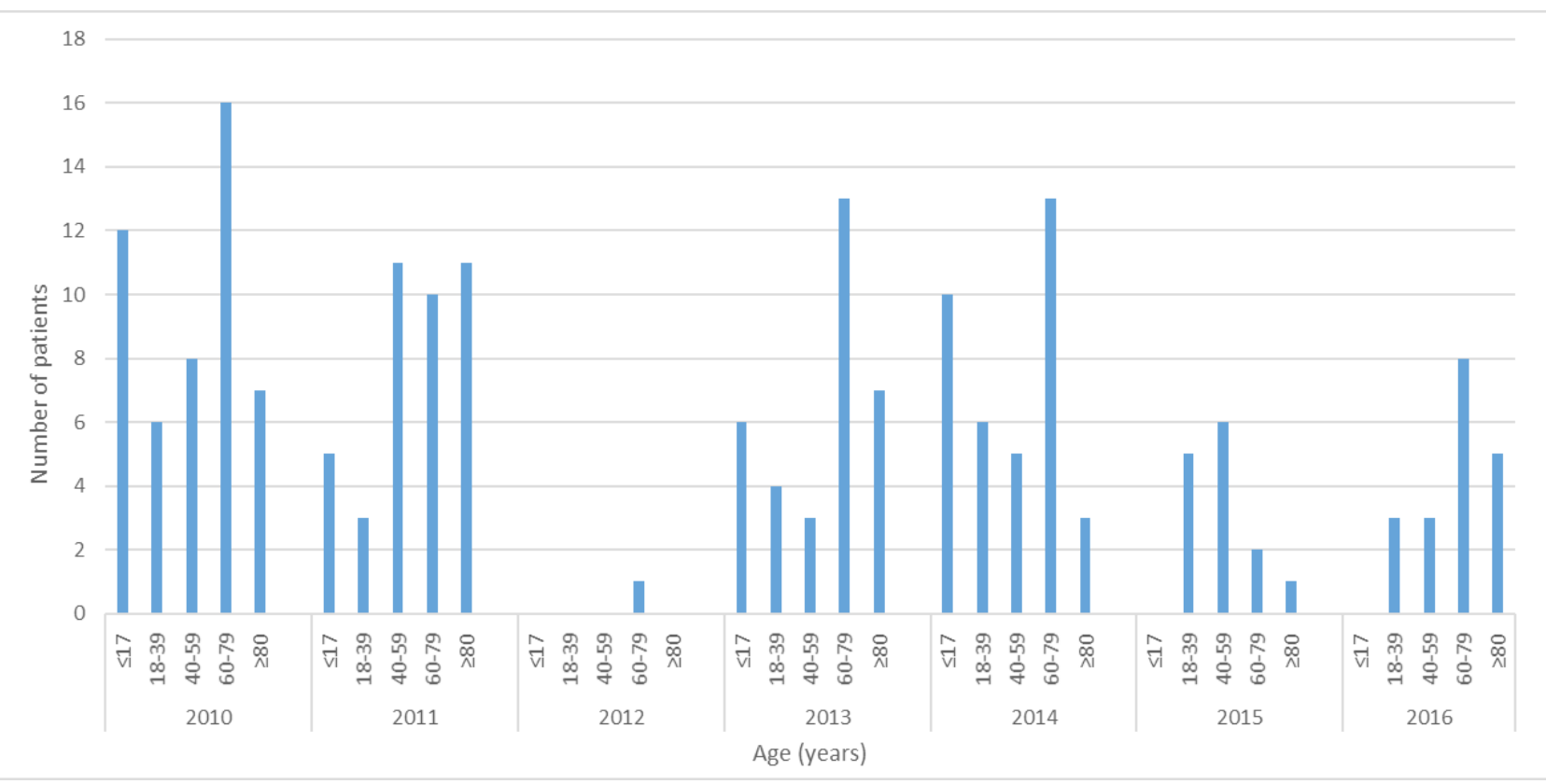

Fig. 3. Age of patients with scabies hospitalized at the Department within 2010-2016

Ryc. 3. Wiek pacjentów chorych na świerzb hospitalizowanych w Klinice w latach 2010-2016 
A correlation can be observed between the number of patients in the 18-39 age group and the number of patients below 18 years old. Along with the decrease in the number of patients below 18 years old the number of patients in the age group 18-39 also decreased (2011, $2012,2015,2016)$ and along with the increase in the number of patients below 18 years old in years 2013, 2014 the number of patients between 18 and 39 years old increased as well. It can be concluded that the disease affects whole families. Children after being infected at school or kindergarten might transfer scabies to their parents. In 2011 an increase in the number of cases of scabies was observed in the age group 40-59 and over 79 years old in comparison to 2010 . In other age groups the number of cases decreased. In 2014 compared to 2013 the number of patients which are 80 years old or older decreased; the number of new infections within the patients between 60 and 79 years old remained the same, and in other groups the number of cases of scabies increased. In 2015 there was a downward trend in the frequency of hospitalization in almost all groups. In 2016 the number of infections of scabies increased in the age group 60-79 and over 79 years old. In other age groups the number of cases decreased.

Many factors can influence the incidence of scabies infestation, among others: age, sex, ethnicity, overcrowding, hygiene and season of the year. In the developed countries the highest rates of infestation are noted in two age groups: kindergarten children and adolescents as well as elderly people (10). In our study adults comprised about $87 \%$ of all patients and their mean age was 53 years. The number of women and men were similar. Similar results were reported by Hegab et al. (12). On the other hand, Kouotou et al. stated that male sex is an independent risk factor for infection (13). Authors pointed out that this might be associated with more frequent bed sharing with other people, less frequent use of soap during bath and not cutting short their fingernails when compared to females (13).
Niską liczbę zachorowań obserwowano również u osób poniżej 18 roku życia. W tej grupie wieku stwierdzono ponad dwukrotny spadek liczby chorych w 2011 w porównaniu z 2010, dwukrotny wzrost zakażonych w 2014 w porównaniu z rokiem 2013 oraz niewystępowanie dermatozy w latach 2012, 2015, 2016.

Można zaobserwować korelację między liczbą pacjentów w grupie wieku 18-39 a liczbą chorych poniżej 18. r.ż. Wraz ze zmniejszeniem się liczby pacjentów w wieku poniżej 18 lat spadała liczba chorych w grupie wieku 18.-39. r.ż. (2011, 2012, 2015, 2016), a wraz ze wzrostem liczby pacjentów poniżej 18. r.ż. rosła liczba chorych między 18.-39. r.ż. (2013, 2014). Można wnioskować, że choroba dotyczy całych rodzin, a dzieci po zarażeniu w szkole przenoszą świerzb na swoich rodziców. W 2011 roku zaobserwowano wzrost liczby zachorowań na świerzb w grupie wieku 40-59 lat i powyżej 79 lat w porównaniu do roku 2010. W pozostałych grupach wieku liczba przypadków zmniejszyła się. W 2014 w porównaniu do 2013 zmniejszyła się grupa chorych w wieku powyżej lub równej 80 lat; bez zmian była liczba nowych zakażeń wśród pacjentów między 60. a 79. r.ż., a w pozostałych grupach liczba przypadków świerzbu wzrosła. W 2015 r. utrzymywała się tendencja spadkowa częstości hospitalizacji niemalże we wszystkich grupach. W roku 2016 liczba zakażeń świerzbem wzrosła $w$ grupie wieku pomiędzy 60. a 79. r.ż. oraz powyżej 79. r.ż. W pozostałych grupach wieku liczba przypadków spadła.

Wiele czynników może wpływać na zapadalność na świerzb, m. in wiek, płeć, pochodzenie etniczne, przeludnienie, higiena oraz pora roku. W krajach rozwiniętych najwyższą zachorowalność odnotowuje się w dwóch grupach wieku: dzieci przedszkolnych i nastolatków oraz osób starszych (10). W naszym badaniu dorośli stanowili około $87 \%$ wszystkich chorych, a średnia ich wieku wynosiła 53 lata. Liczby kobiet i mężczyzn były zbliżone. Podobne wyniki uzyskali Hegab i wsp. (12).

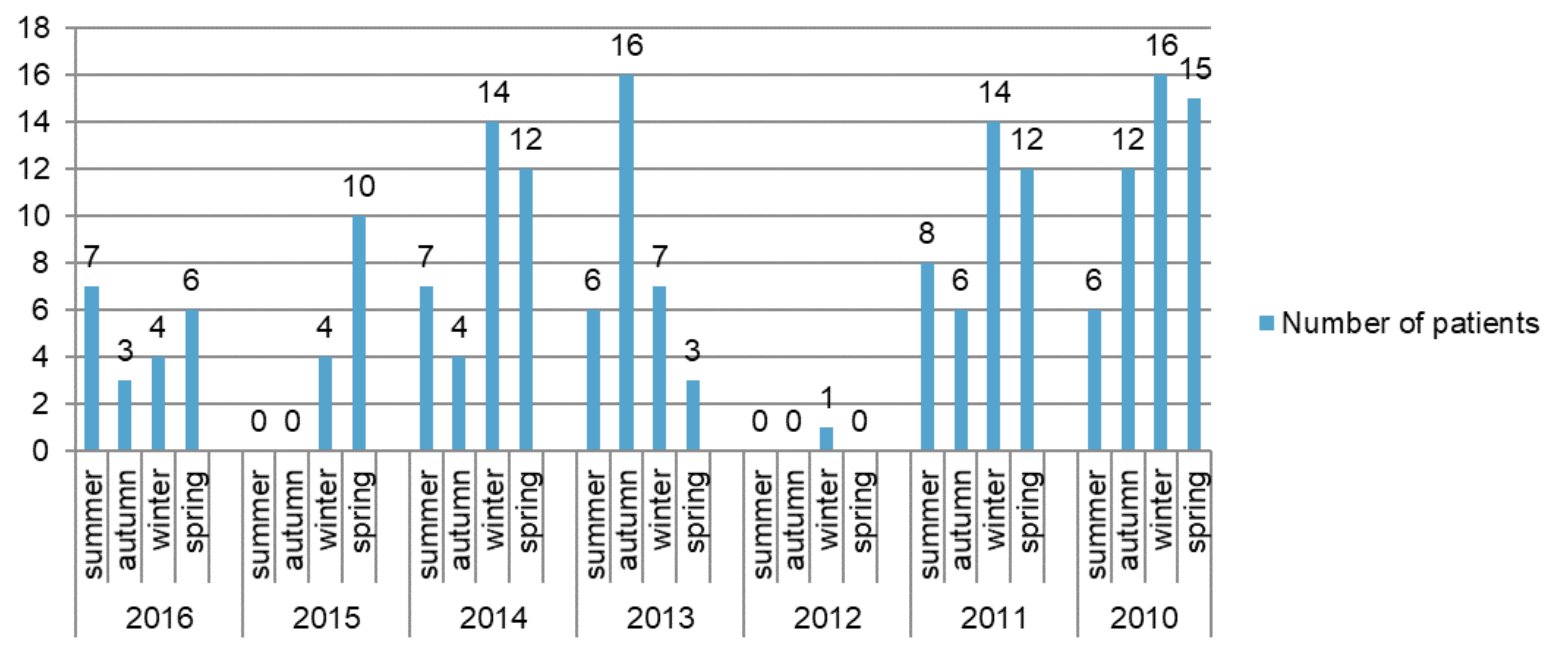

Fig. 4. Scabies - number of patients hospitalized at the Department in years 2010-2016 considering seasons of the year Ryc.4. Świerzb - liczba chorych hospitalizowanych w klinice w latach 2010-2016 z uwzględnieniem pór roku 
Table 2. Accompanying dermatoses in patients with scabies considering their age

Tabela 2. Dermatozy współistniejące pacjentów ze świerzbem z uwzględnieniem wieku

\begin{tabular}{|c|c|c|c|c|c|c|}
\hline Dermatozy wspólistniejące & $\leq 17$ r.z. & 18-39 r.ż. & 40-59 r.ż. & 60-79 r.ż. & $\geq 80$ r.ż. & Razem \\
\hline Wyprysk & $\begin{array}{l}\mathbf{0 / 3 3} \\
(0 \%)\end{array}$ & $\begin{array}{c}\mathbf{3} / \mathbf{2 7} \\
(11.1 \%)\end{array}$ & $\begin{array}{c}\mathbf{8 / 3 6} \\
(22.2 \%)\end{array}$ & $\begin{array}{c}\mathbf{6} / \mathbf{6 3} \\
(9.5 \%)\end{array}$ & $\begin{array}{c}\mathbf{5 / 3 4} \\
(14.7 \%)\end{array}$ & $\begin{array}{l}\mathbf{2 2 / 1 9 3} \\
(11.4 \%)\end{array}$ \\
\hline Wtórne zakażenie & $\begin{array}{c}\mathbf{5 / 3 3} \\
(15.2 \%) \\
\end{array}$ & $\begin{array}{c}\mathbf{6 / 2 7} \\
(22.2 \%) \\
\end{array}$ & $\begin{array}{c}\mathbf{3 / 3 6} \\
(8.3 \%) \\
\end{array}$ & $\begin{array}{l}\mathbf{0 / 6 3} \\
(0 \%)\end{array}$ & $\begin{array}{l}\mathbf{0 / 3 4} \\
(0 \%)\end{array}$ & $\begin{array}{l}\mathbf{1 4 / 1 9 3} \\
(7.3 \%)\end{array}$ \\
\hline $\begin{array}{c}\text { Kontaktowe } \\
\text { zapalenie skóry }\end{array}$ & $\begin{array}{l}\mathbf{0 / 3 3} \\
(0 \%)\end{array}$ & $\begin{array}{l}\mathbf{0} / 27 \\
(0 \%)\end{array}$ & $\begin{array}{c}\mathbf{2 / 3 6} \\
(5.6 \%)\end{array}$ & $\begin{array}{c}\mathbf{8} / \mathbf{6 3} \\
(12.7 \%)\end{array}$ & $\begin{array}{c}\mathbf{3 / 3 4} \\
(8.8 \%)\end{array}$ & $\begin{array}{l}\mathbf{1 3 / 1 9 3} \\
(6.7 \%)\end{array}$ \\
\hline Luszczyca & $\begin{array}{l}\mathbf{0 / 3 3} \\
(0 \%)\end{array}$ & $\begin{array}{c}1 / 27 \\
(3.7 \%)\end{array}$ & $\begin{array}{c}\mathbf{4} / \mathbf{3 6} \\
(11.1 \%)\end{array}$ & $\begin{array}{c}\mathbf{5 / 6 3} \\
(7.9 \%)\end{array}$ & $\begin{array}{c}\mathbf{2 / 3 4} \\
(5.9 \%)\end{array}$ & $\begin{array}{l}\mathbf{1 2} / 193 \\
(6.2 \%)\end{array}$ \\
\hline Grzybica skóry i paznokci & $\begin{array}{c}\mathbf{2} / \mathbf{3 3} \\
(6.1 \%)\end{array}$ & $\begin{array}{l}\mathbf{0} / 27 \\
(0 \%)\end{array}$ & $\begin{array}{c}2 / 36 \\
(5.6 \%)\end{array}$ & $\begin{array}{c}\mathbf{6} / \mathbf{6 3} \\
(9.5 \%)\end{array}$ & $\begin{array}{c}\mathbf{1 / 3 4} \\
(2.9 \%)\end{array}$ & $\begin{array}{l}\mathbf{1 1 / 1 9 3} \\
(5.7 \%)\end{array}$ \\
\hline Atopowe zapalenie skóry & $\begin{array}{l}1 / 33 \\
(3 \%) \\
\end{array}$ & $\begin{array}{c}\mathbf{4} / \mathbf{2 7} \\
(14.8 \%) \\
\end{array}$ & $\begin{array}{c}\mathbf{1 / 3 6} \\
(2.8 \%) \\
\end{array}$ & $\begin{array}{l}\mathbf{0 / 6 3} \\
(0 \%) \\
\end{array}$ & $\begin{array}{l}\mathbf{0 / 3 4} \\
(0 \%) \\
\end{array}$ & $\begin{array}{c}6 / 193 \\
(3.1 \%) \\
\end{array}$ \\
\hline Czyraki & $\begin{array}{l}1 / 33 \\
(3 \%) \\
\end{array}$ & $\begin{array}{c}\mathbf{1 / 2 7} \\
(3.7 \%) \\
\end{array}$ & $\begin{array}{c}\mathbf{2 / 3 6} \\
(5.6 \%) \\
\end{array}$ & $\begin{array}{c}\mathbf{1 / 6 3} \\
(1.6 \%) \\
\end{array}$ & $\begin{array}{l}\mathbf{0 / 3 4} \\
(0 \%) \\
\end{array}$ & $\begin{array}{l}\mathbf{5 / 1 9 3} \\
(2.6 \%) \\
\end{array}$ \\
\hline
\end{tabular}

In our study, patients most frequently reported to the doctor during winter (31\%) and spring (30\%) (Fig. 4.). Most hospitalizations were in 2010, 2011 and 2014 , the lowest in 2012, only one - the patient who had symptoms in the winter. In the summer, patients are the least susceptible to scabies. Over the years, it was between 0-8 people, in 2012 and 2015 no illnesses were observed. This could be related to the higher temperatures prevailing at this time. At $15^{\circ} \mathrm{C}$, mites survive outside the host for a week or longer, and at $24^{\circ} \mathrm{C}$ only 1-2 days. Studies have shown that even higher temperatures drastically shortened their survival time due to dehydration and inability to maintain water balance. So in the summer, mites die quickly, and in the winter they survive for longer, so it is easier for them to find a host and infect him (14). Autumn is the third consecutive season of the year in terms of incidence of scabies, however, there are more fluctuations in the number of hospitalizations, $0-16$ in the period of 7 analyzed years; the highest in 2013. In 2010-2016, a decrease in the number of hospitalizations due to scabies from 49 patients to 22 was observed. This may be due to the more frequent use of permethrin in local treatment in outpatient settings.

Human is infected with larvae, nymphs or fertilized female mite through direct skin-to-skin contact, as well as indirectly- through items $(2,3)$. Familial infestations with scabies constitute over a half of all scabies cases (2). In our study previous contact with infected people was reported only by $21 \%$ patients. Skin lesions that are observed in scabies infection that are caused by the parasite's invasion usually appear within 2 weeks after infestation. Particulary infectious (due to an enormous number of parasites, even up to millions) variant is norwegian (crusted) scabies $(2,15)$ which mainly affects elderly people, with immunosupression, malignant neoplasms and treated with immunosupressive and
Z kolei Kouotou i wsp. stwierdzili, żę płeć męska jest niezależnym czynnikiem zwiększającym ryzyko zarażenia (13). Autorzy wskazali, że może mieć to związek z częstszym dzieleniem łóżka z innymi osobami, rzadszym używaniem mydła do kąpieli oraz nieobcinaniem krótko paznokci w porównaniu do dziewcząt (13).

W naszym badaniu, pacjenci najczęściej zgłaszali się do lekarza w zimie (31\%) i na wiosnę (30\%) (Ryc. 4.). Najwięcej hospitalizacji w tym okresie było w latach 2010, 2011 oraz 2014, najmniej w 2012 roku, zaledwie jeden - pacjent, u którego objawy wystąpiły zimą. Latem pacjenci są najmniej podatni na zachorowanie na świerzb. Na przestrzeni lat było to między 0-8 osób, w tym w 2012 oraz 2015 r. nie zaobserwowano żadnych zachorowań. Można to powiązać z wyższymi temperaturami panującymi w tym czasie. W temperaturze $15^{\circ} \mathrm{C}$ świerzbowce przeżywają poza organizmem gospodarza tydzień lub dłużej, a w temperaturze $24^{\circ} \mathrm{C}$ tylko $1-2$ dni. Badania wykazały, że jeszcze wyższe temperatury drastycznie skracały ich czas przeżycia z powodu odwodnienia i niezdolności do utrzymania równowagi wodnej. Tak więc latem świerzbowce szybko giną, a zimą dłużej przeżywają, więc łatwiej jest im znaleźć gospodarza i go zakazić (14). Jesień jest trzecią kolejną porą roku pod względem częstości występowania świerzbu, jednak widoczne są większe wahania w liczbie hospitalizacji, $0-16 \mathrm{w}$ okresie 7 analizowanych lat; najwięcej w $2013 \mathrm{r}$. W latach 2010-2016 zaobserwowano zmniejszanie się liczby hospitalizacji z powodu świerzbu z 49 pacjentów do 22. Może być to spowodowane częstszym stosowaniem permetryny w leczeniu miejscowym $\mathrm{w}$ warunkach ambulatoryjnych.

Człowiek zaraża się larwą, nimfami lub zapłodnioną samicą przez styczność bezpośrednią, jak również pośrednio poprzez przedmioty $(2,3)$. Rodzinne zarażenia świerzbem stanowią ponad połowę wszystkich przypadków zarażenia (2). W naszym badaniu uprzed- 
immunomodulatory drugs, as well as mentally ill patients $(2,10,16)$. This variant is characterized by vesicles and massive, hyperkeratotic crusts without typical for the regular scabies, papules and pruritus which makes the diagnosis more difficult $(2,16)$. Skin lesions are extensive and affect different parts of the body including, what is typical, hair scalp and even face (2). Among our patients we noted only one case of norwegian scabies.

Pruritus is a characteristic symptom for scabies $(2,3,10)$. It typically worsens at night due to warmth of the body underneath the linen $(2,10)$. Also in our study, it was the most common subjective symptom, reported by almost $94 \%$ of all patients. Patients should be informed that after completing the treatment the pruritus can persist for couple more weeks. If it does not resolve after 4 weeks it is advised to start the diagnostic process of its etiology again $(3,17)$.

Most of the patients hospitalized in our department had coexisting dermatological condition, such as eczema, psoriasis, atopic dermatitis, fungal skin and nail infection and furuncles (Tab.2.). Scabies can be complicated by colonization of skin lesions with microorganisms or secondary bacterial infection, such as impetigo. This complication is common in regions with tropical and subtropical climate. In our study, secondary bacterial infection was observed more frequently among children than in adults $(15.2 \%$ vs $5.6 \%)$. Scabies, as well as bacterial skin infections are associated with poverty, overpopulation, poor sanitary conditions, lack of hygiene and malnourishment $(7,18)$. In a study carried out by Edison et al. among 1139 in American Samoa, secondary bacterial infection was observed in 604 (53\%) patients with scabies (19). In a study conducted by Esposito and Veraldi among 89 patients with scabies only $5(5.6 \%)$ patients had positive bacterial culture from skin lesions (18). In our study, impetiginization was noted in 14 (7.3\%) of patients with scabies. According to the literature, psoriasis is more common in patients with scabies. There is a possible association between scabies and increased risk of developing psoriasis. Psoriasis should be taken under consideration in differential diagnosis of treatment-resistant scabies (20).

Scabies recurrence was observed in $14 \%$ of patients' documentation. According to the literature, scabies recurrence most frequently concerns elderly, patients in long-term care facilities, patients with immunosuppression and patients with dementia (21).

There are several treatment options for scabies, topical agents as well as oral medication- ivermectin can be used. In Poland oral ivermectin is not registered for use in humans. Oral treatment should be preferred in patients who do not tolerate topical treatment or non-compliant patients, as well as in scabies outbreak in developing countries $(3,22)$. nią styczność z osobami chorymi zgłosiło zaledwie 21\% pacjentów. Zmiany skórne obserwowane w przebiegu świerzbu związane z inwazją pasożyta zwykle pojawiają się do 2 tygodni po zarażeniu. Szczególnie zaraźliwa (ze względu na ogromną liczbę pasożytów, nawet do kilku milionów) postacią jest świerzb norweski $(2,15)$, który dotyka głównie osoby starsze, $\mathrm{z}$ obniżoną odpornością, z nowotworami złośliwymi i leczone lekami immunosupresyjnymi lub immunomodulującymi, jak również pacjentów chorych psychicznie $(2,10,16)$. Charakterystyczna jest obecność pęcherzyków i masywnych, nawarstwionych strupów oraz brak typowych dla postaci klasycznej grudek i świądu, przez co szybkie postawienie właściwej diagnozy jest utrudnione $(2,16)$. Zmiany są rozległe i zajmują różne części ciała, w tym, co charakterystyczne, skórę owłosioną głowy, a nawet twarz (2). Wśród naszych pacjentów stwierdzono tylko jeden przypadek świerzbu norweskiego.

Świąd jest charakterystycznym objawem towarzyszącym świerzbowi $(2,3,10)$. Typowo nasila się $\mathrm{w}$ nocy $\mathrm{w}$ związku $\mathrm{z}$ rozgrzaniem ciała pod pościelą w łóżku $(2,10)$. Również w naszym badaniu był to najczęściej zgłaszany objaw subiektywny, odnotowany u prawie 94\% wszystkich chorych. Pacjenci powinni być poinformowani, że po zakończeniu leczenia świąd może utrzymywać się jeszcze przez kilka tygodni. Jeżeli nie ustępuje po czterech tygodniach, wskazana jest ponowna diagnostyka jego przyczyny $(3,17)$.

Wśród danych o pacjentach $\mathrm{z}$ naszej Kliniki u większości zanotowano współistnienie innych schorzeń dermatologicznych, m.in. wyprysku, łuszczycy, atopowego zapalenia skóry, grzybicy skóry i paznokci oraz czyraków (Tab. 2.). Świerzb może być powikłany kolonizacją zmian skórnych przez drobnoustroje lub wtórnym zakażeniem bakteryjnym, np. zliszajowaceniem. Jest to powikłanie powszechne w krajach o klimacie tropikalnym i subtropikalnym. Zaobserwowano, że powikłanie w postaci wtórnego zakażenia zmian skórnych częściej występowało u dzieci niż u dorosłych (15.2\% vs 5.6\%). Zarówno świerzb, jak i ropne zakażenia skóry są chorobami związanymi z ubóstwem, przeludnieniem, brakiem odpowiednich warunków sanitarnych i higieny oraz niedożywieniem $(7,18)$. W badaniu przeprowadzonym przez Edison i wsp. wśród 1139 dzieci na terenach Amerykańskich Wysp Samoa wtórne zakażenie bakteryjne opisano aż u 604 (53\%) pacjentów ze świerzbem (19). W badaniu przeprowadzonym we Włoszech przez Esposito i Veraldi wśród 89 pacjentów ze świerzbem, jedynie u $5(5,6 \%)$ pacjentów otrzymano dodatnie wyniki posiewów bakteryjnych (18). W naszym badaniu zliszajowacenie dotyczyło $7,3 \%$ pacjentów ze świerzbem. W literaturze są doniesienia, że u pacjentów ze świerzbem częściej występuje łuszczyca. Wykazano prawdopodobny związek między przebyciem świerzbu 
Among topical treatments for scabies, permethrin appears to be the most effective. Permethrin kills not only parasites but also their eggs. Permethrin is considered to have low toxicity as its absorption through the skin is minimal $(3,23)$. It was the most frequently used anti-scabies medication in our patients (57\%).

Apart from pharmacological treatment, appropriate sanitary-hygienic regime is crucial in scabies management, since even effective topical therapy does not ensure therapeutic success without compliance with the sanitary-hygienic rules (24). The necessary step is washing all of the used bed linens, towels and clothes in high temperature (above $50^{\circ} \mathrm{C}$ ) and ironing them (3). All of the household members and people who had close contact with a person with scabies should be treated (10). Children should stay at home and should not go to school or kindergarten until treatment is completed (25).

Scabies in children is characterized by different location of skin lesions and certain differences in treatment $(3,12,26)$. Skin lesions in children most commonly are present on lateral sides of hand fingers, skin between the fingers, wrists, skin folds, buttocks, navel, nipples and genitals. Apart from typical location, lesions can also appear on the palms of the hands and plantar surface of the feet, as well as on face, scalp and in diaper area in infants (24).

One of the limitations of our study was the lack of information about the exact reason for referral of the patients with scabies to our Department in some of the cases. From our observations it is usually a result of ambulatory treatment failure which can be caused by non-compliance with sanitary regimen or lack of treatment of all of the household members which can lead to reinfection. We did not find the exact reasons for the referrals but some of the patients were referred to the Department of Dermatology and Venereology from nursing homes and in some cases whole families were hospitalized because of inappropriate, poor living and housing condition. Unfortunately, the retrospective character of our study does not allow us to obtain this information about the studied group.

\section{CONCLUSIONS}

1. One should remember about many possible clinical symptoms of scabies, as well as the specific location of the lesions, depending on age, which may result in earlier, correct diagnosis, administration of proper treatment and limitation of the spread of infection.

2. Scabies is an infectious and contagious disease that is more common in elderly people who suffer from multiple comorbidities such as hypertension, obesity, diabetes, atrial fibrillation, heart failure and alcohol dependence. a zwiększonym ryzykiem zachorowania na łuszczycę. Łuszczycę należy brać pod uwagę w diagnostyce różnicowej przy występowaniu świerzbu opornego na leczenie (20).

Nawrót świerzbu wykazano w 14\% dokumentacji pacjentów. Według literatury nawrót zmian skórnych dotyczy najczęściej starszych pacjentów przebywających w placówkach opiekuńczych, z osłabioną odpornością oraz demencją (21).

Istnieje kilka możliwości leczenia świerzbu, zastosowanie mają tu głównie preparaty stosowane miejscowo, również możliwe jest doustne leczenie iwermektyną - w Polsce nie jest dostępna w postaci doustnej do stosowania u ludzi . Powinno być ono preferowane u osób nietolerujących leczenia miejscowego lub niestosujących się do zaleceń, jak również przy epidemiach świerzbu w krajach ubogich $(3,22)$. Wśród leków do stosowania miejscowego największą skuteczność przypisuje się permetrynie. Jest to preparat zabijający nie tylko pasożyty, ale także ich jaja, jednocześnie o minimalnym stopniu absorpcji, co czyni go wyjątkowo mało toksycznym $(3,23)$. Był to właśnie najczęściej stosowany środek przeciwświerzbowcowy u naszych chorych $(57 \%)$.

Oprócz leczenia farmakologicznego w terapii świerzbu niezwykle istotne znaczenie ma utrzymanie odpowiedniego reżimu sanitarno-higienicznego, gdyż nawet po skutecznym leczeniu miejscowym preparatami nie osiągnie się ostatecznego powodzenia bez przestrzegania poniższych zasad (24). Konieczne jest wypranie używanej dotychczas pościeli, ręczników i ubrań w wysokiej temperaturze (powyżej $50^{\circ} \mathrm{C}$ ) oraz ich wyprasowanie (3). Należy leczyć wszystkich domowników i osoby ze styczności (10). Dzieci powinny przebywać w domu do momentu ukończenia aplikacji leku (nie uczęszczać do szkoły, przedszkola itp.) (25).

Oddzielnego omówienia wymaga świerzb w populacji dziecięcej. Charakteryzuje się on przede wszystkim odmiennym umiejscowieniem zmian skórnych, jak i pewnymi różnicami w leczeniu $(3,12,26)$. Zmiany skórne u dzieci najczęściej występują na bocznych powierzchniach palców rąk, przestrzeniach międzypalcowych, nadgarstkach, zgięciach i fałdach skórnych, pośladkach, a także w okolicy pępka, brodawek sutkowych i narządów płciowych. Poza typową lokalizacją zmiany mogą pojawiać się na dłoniowej powierzchni rąk, podeszwowej stóp oraz na twarzy i głowie, a u niemowląt również w okolicy pieluszkowej (24).

W kwestii ograniczeń naszego badania niestety rzadko znany był dokładny powód kierowania pacjentów z różnych poradni w regionie, gdzie najczęściej prowadzone jest leczenie pacjentów ze świerzbem. Z naszych obserwacji wynika, że zwykle jest to spowodowane niepowodzeniami w leczeniu ambulatoryjnym, co może wynikać z nieprzestrzegania reżimu sanitarne- 
3. In order to achieve full therapeutic success it is necessary remember about the importance of compliance with the sanitary and hygienic regimen.

\section{REFERENCES}

1. Sunderkotter C, Feldmeier H, Folster-Holst R et al. S1 guidelines on the diagnosis and treatment of scabies - short version. J Dtsch Dermatol Ges 2016;14:11551167.

2. Buczek A.: Choroby pasożytnicze. Epidemiologia, diagnostyka, objawy. Wyd. 4. Lublin: Koliber- Oficyna Wydawnicza Fundacji na Rzecz Zwalczania Kleszczy i Profilaktyki w Chorobach Odkleszczowych; 2010,326331.

3. Monsel G, Chosidow O. Management of scabies. Skin Therapy Lett 2012;17(3):1-4.

4. GBD 2015 Disease and Injury Incidence and Prevalence Collaborators. Global, regional, and national incidence, prevalence, and years lived with disability for 310 diseases and injuries, 1990-2015: a systematic analysis for the Global Burden of Disease Study 2015. Lancet 2016;388(10053):1545-602.

5. Brochocka A., Szczukowska H., Kasprzak J. Retrospektywna ocena zachorowań na świerzb (scabies) - obecnie nie rejestrowanej, a w przeszłości najczęściej notowanej parazytozy na terenie Polski. Probl Hig Epidemiol 2014,95(1):62-66.

6. World Health Organization. Report of the tenth meeting of the WHO Strategic and Technical Advisory Group for neglected tropical diseases. Geneva: WHO; 2017: 6-7.

7. Chang AY, Fuller LC. Scabies-An Ancient Disease With Unanswered Questions in Modern Times. JAMA Dermatol 2018;154(9):999-1000

8. Engelman D, Fuller LC, Steer AC. Consensus criteria for the diagnosis of scabies: a Delphi study of international experts. PLoS Negl Trop Dis 2018;12: e0006549

9. Karimkhani C, Colombara DV, Drucker AM, et al. The global burden of scabies: a cross-sectional analysis from the Global Burden of Disease Study 2015. Lancet Infect Dis 2017;17(12):1247-1254.

10. Hay RJ, Steer AC, Engelman D, et al. Scabies in the developing world - its prevalence, complications, and management. Clin Microbiol Infect 2012;18(4):313-323.

11. Romani L, Whitfeld MJ, Koroivueta J, et al. Mass drug administration for scabies control in a population with endemic disease. N Engl J Med 2015;373:2305-2313.

12. Hegab DS, Kato AM, Kabbash IA, Dabish GM. Scabies among primary schoolchildren in Egypt: sociomedical environmental study in Kafr El-Sheikh administrative area. Clinical, Cosmetic and Investigational Dermatology $2015 ; 8,105-111$.

13. Kouotou EA, Nansseu JRN, Kouawa MK, Zoung-Kanyi Bissek AC. Prevalence and drivers of human scabies among children and adolescents living and studying in Cameroonian boarding schools. Parasites \& Vectors 2016;9,400. go czy braku leczenia wszystkich współdomowników, co może prowadzić do reinfekcji. Nie udało nam się poznać dokładnych przyczyn, dla których kierowano do nas pacjentów, ale $\mathrm{z}$ doświadczenia klinicznego dermatologów z Kliniki Dermatologii UMB wiemy, że kierowano pacjentów $\mathrm{z}$ domów opieki lub hospitalizowano całe rodzeństwo $\mathrm{z}$ danej rodziny, z powodów niedostatecznych, złych warunków socjalno-bytowych. Niestety, charakter retrospektywny naszej pracy uniemożliwia pogłębienie tych informacji w obrębie badanej grupy.

\section{WNIOSKI}

1. Należy pamiętać o wielu możliwych objawach klinicznych choroby, jak również swoistej lokalizacji zmian, również zależnej od wieku, co przekłada się na wcześniejsze, poprawne postawienie rozpoznania, wdrożenie właściwego leczenia i ograniczenie szerzenia się zakażenia.

2. Świerzb jest chorobą zakaźną i zaraźliwą, która częściej dotyczy osób w wieku starszym, obciążonych chorobami ogólnoustrojowymi, takimi jak jak nadciśnienie tętnicze, otyłość, cukrzyca, migotanie przedsionków, niewydolność serca i uzależnienie od alkoholu.

3. W leczeniu należy pamiętać o równoległym przestrzeganiu reżimu sanitarno-higienicznego, w celu osiągnięcia pełnego sukcesu terapeutycznego.

14. Arlian LG, Morgan MS. A review of Sarcoptes scabiei: past, present and future. Parasit Vectors 2017;10(1):297.

15. Sánchez-Borges M, González-Aveledo L, Capriles-Hulett A, et al. Scabies, crusted (Norwegian) scabies and the diagnosis of mite sensitization. Allergol Immunopathol (Madr) 2018;46(3):276-280.

16. Yelamos O, Mir-Bonafe JF, Lopez-Ferrer A, et al. Crusted (Norwegian) scabies: an under-recognized infestation characterized by an atypical presentation and delayed diagnosis. J Eur Acad Dermatol Venereol 2016;30:483-485.

17. Sashidharan PN, Basavaraj S, Bates CM. 2016 UK National Guideline on the Management of Scabies. https:// www.bashhguidelines.org/media/1137/scabies-2016. pdf

18. Esposito L, Veraldi S. Skin bacterial colonizations and superinfections in immunocompetent patients with scabies. Int J Dermatol 2018;57(10):1218-1220.

19. Edison L, Beaudoin A, Goh L, et al. Scabies and bacterial superinfections among American Samoan children, 2011-2012. PLoS One 2015;10(10):e0139336.

20. Liu JM, Lin CY, Chang FW, et al. Increased risk of psoriasis following scabies infection: A nationwide population-based matched-cohort study. J Dermatol 2018;45(3):302-308. 
21. Makigami K, Ohtaki N, Ishii N, et al. Risk factors for recurrence of scabies: a retrospective study of scabies patients in a long-term care hospital. J Dermatol 2011;38(9):874-879.

22. Burgdorf WHC, Plewig G., Wolff HH, Landhalter M. Braun-Falco Dermatologia. Wyd.2 Lublin: Wydawnictwo Czelej; 2010,345-350.

23. Rezaee E, Goldust M, Alipour H. Treatment of scabies: Comparison of Lindane 1\% vs Permethrin 5. Skinmed 2015; 13(4):283-286.

24. Flisiak I, Kiluk P. Świerzb i wszawica u dzieci - aktualne zasady postępowania. Standardy Medyczne/ Pediatria 2017;14:251-257.
Received: 5.09.2018

Accepted for publication: 24.01.2019

Otrzymano: 5.09.2018 r.

Zaakceptowano do publikacji: 24.01.2019 r.

\section{Address for correspondence:}

Adres do korespondencji:

lek. Julia Nowowiejska

julka.nw@gmail.com

Klinika Dermatologii i Wenerologii

Uniwersytet Medyczny w Białymstoku

ul. Żurawia 14, 15-540 Białystok 